\title{
Building Information Modeling (BIM) for Dams-Literature Review and Future Needs
}

\author{
Catur Ayu Wahyuningrum ${ }^{1, *}$, Y. Chandra Sari ${ }^{1}$, Nindyo Cahyo Kresnanto ${ }^{2}$ \\ 'Dam Center, Directorate of Water Resources - Ministry of Public Works and Housing \\ ${ }^{2}$ Master of Civil Engineering, Faculty of Engineering, Janabadra University \\ ${ }^{*}$ Corresponding authors: caturayu40262@gmail.com
}

SUBMITTED 15 November 2019 REVISED 13 December 2019 ACCEPTED 15 December 2019

\begin{abstract}
Dam is a structure with high beneficial values and these include, serving as the source of raw water supply and electrical energy, ensuring flood reduction, tourist attractions, and habitat protection. It is, however, associated with a very complex development process ranging from the planning/design, construction, as well as operation and maintenance. Therefore, there is a need for special attention, accuracy, and good coordination at every stage from the parties involved as well as the integration of all fields starting from the Architecture, Engineering, and Construction (AEC) elements. Moreover, ensuring an effective and efficient construction process presents a serious challenge for the owner/government, designers, consultants and contractors which is now being resolved through the use of a technological innovation known as the Building Information Modeling (BIM).

This study was conducted to determine the scientific developments of BIM for dam management and also to identify further related areas to be researched in the future. Moreover, the analysis was concentrated on the potential added value of the technological innovations on dams, explained its advantages, and assesses the potential challenges hampering its effectiveness in Indonesia. It was discovered that the use of BIM for dam projects is possible as long as there are adequate government regulations and the availability of qualified human resources while the consequence would be an increase in the investment cost. The findings of this research are expected to encourage the use of BIM in dam construction and management in Indonesia and also to increase efficiency and effectiveness in all aspects.
\end{abstract}

KEYWORDS Building Information Modeling; Construction; Dam; AEC

(c) The Author(s) 2020. This article is distributed under a Creative Commons Attribution-ShareAlike 4.0 International license.

\section{INTRODUCTION}

Dams are defined as man-made barriers built on natural terrain to control or store water (Schurer, et al. 2002). They are further described as complex facilities usually comprising of water reservoirs or control structures, reservoirs, spillways, outlet works, powerhouses, and canals or drains (U.S. Department of Homeland Security, 2007). There are several high benefits attached to dams, and according to the U.S. Department of Homeland Security (2007), they include recreation, flood control, water storage, irrigation, mine tailings, electrical generation, debris control, and navigation. In addition to the aforementioned, they are also useful as a source of raw water, fisheries, and conservation (Mulyono, 2017). There are, however, complex problems attached to the development of dams to provide these benefits and they vary from the design/planning and construction stages to the maintenance operations involving owners/government, planners, consultants, and executors. In recent times, these challenges are now being resolved through the use of a technological innovation called the Building Information Modeling (BIM).

According to Paul (2018), this method is being applied for infrastructural projects in developed countries. However, Indonesia is also currently heading towards the process of adopting technology in constructing infrastructures. For example, in the Appendix to the Minister of Public Works and Housing Regulation No. 22 of 2018 concerning State Buildings, it is stated that 
BIM needs to be applied to non-modest state buildings with criteria of the area above 2,000 $\mathrm{m}^{2}$ and more than 2 (two) floors (Ministry of Public Works and Housing, 2018) while there are no mandatory regulations on the application of BIM to other infrastructures such as roads, bridges, dams, etc.

The fast implementation of this technology is observed with the Directorate General of Human Settlements where it has been applied for sever projects owned by the agency (BIM Ministry of Public Works and Housing, 2019b). Moreover, the Directorate General of Highways has also implemented the use of BIM in several toll projects (Directorate General of Human Settlements, 2018) and have also planned to enact mandatory policies by 2020 which has led to the creation of three working groups to review and compile a legal basis for the implementation, preparation of technical guidelines, manuals, and modules as well as training curriculum on BIM (BIM Ministry of Public Works and Housing, 2019a).

BIM has been widely used in building projects but there are very few applications in Civil Engineering (Wang et.al. 2018) especially for dams. For example, South Korea has utilized the technology mostly in the design phase of dam construction and also for process management, stimulation, and advertising (Ju \& Seo, 2012). In
Indonesia, BIM is now being applied by contractors in several dam projects based on requests from the Directorate General of Water Resources but still limited by the lack of regulations mandating its use both at the planning stage by the consultant and the construction implementation stage by the contractor.

Based on these descriptions, there is a need to study the use of BIM in the dam construction process. Therefore, this paper discusses several studies conducted in relation to this topic in order to determine the scientific developments in the field and also to clarify further research to be developed and conducted on dam projects in Indonesia.

\section{METHODOLOGY}

The paper was conducted by analyzing the use of BIM in infrastructure projects including dam projects both inside and outside Indonesia through the use of academic papers from several construction science journals, book chapters, dissertations, and conference proceedings with a focus on dams and BIM. Papers and articles used were classified based on their use of keywords such as BIM, dams, and the use of BIM on dams. Meanwhile, qualitative analysis was used to identify the interaction of papers from different backgrounds. Moreover, the research process flow is shown in Figure 1.

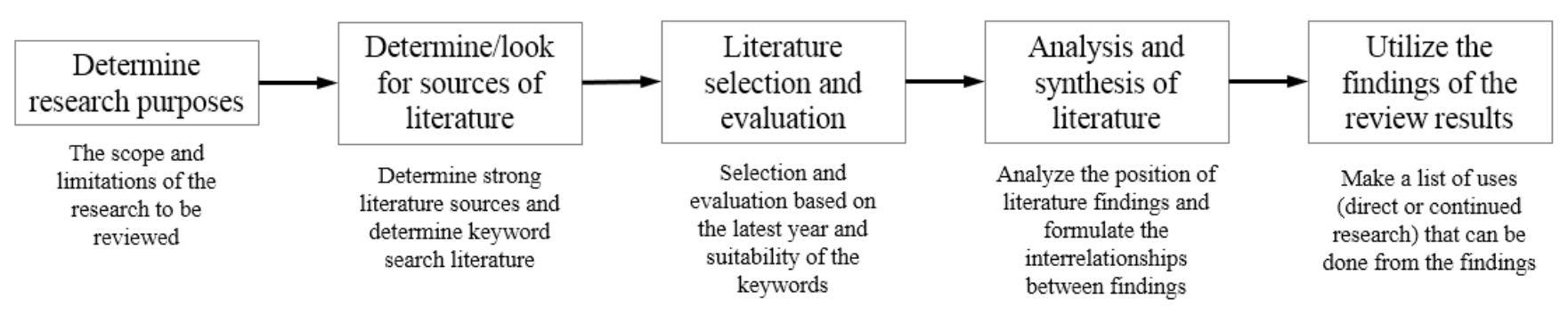

Figure 1. Research Methodology Review 


\section{RESULT AND DISCUSSION}

\subsection{Current Application of BIM in AEC}

BIM is a 3D model-based process that provides Architecture, Engineering and Construction (AEC) insight and tools for professionals to plan, build, manage buildings and infrastructure more efficiently (Autodesk, 2019). It is also useful for generating and managing data such as geometry, spatial relationships, quantities, the properties of components, etc. during the life cycle of a building (Ratajczak et al., 2019). BIM also has the ability to transform how a building is designed and built and also to facilitate multi-disciplinary coordination, integration of 3D design, analysis, cost estimation, and construction scheduling (McArthur, 2015).

According to Azhar (2011), the technology can be used for several purposes including visualization, fabrication/shop drawings, code reviews, cost estimation, sorting of construction, detecting conflicts, disturbances and clashes, forensic analysis, and facility management. Moreover, BIM application in several phases of project development is in different types as shown in Figure 2. These include 2D and 3D which are the basic form with limited use such as documentation and visualization, 4D which requires additional time and mostly used to optimize planning through schedule, 5D which comes with additional costs and used to develop a more efficient, cost-effective, and sustainable construction through cost/estimation, 6D which provides additional energy analysis and used to regulate overall energy consumption for as-built operation or sustainability, and 7D for the optimization of asset and facility management from the design to operations and maintenance phase (Kacprzyk \& Kępa, 2014; Ministry of Public Works and Housing, 2017).

A survey conducted by Eadie, etal. (2013) reported the utilization of BIM at the stage of design was $55 \%$, detailed design and auction was 52\%, construction was $35 \%$, feasibility was $27 \%$ while the operation and maintenance stages were found to be $9 \%$. Moreover, the BIM application was discovered to be effective in all stages of the project by providing several benefits such as the improvement in the quality of design, ease of implementation, ability to share information, reduced construction costs, design errors and construction time, improve energy efficiency, and support construction and project management.

McGraw Hill Construction data (2014) also showed $90 \%$ of planning teams and $70 \%$ of general contractors in the UK use BIM without the request of the owner while $52 \%$ was based on requests. Moreover, other indicators showed that in 2016, 55\% of infrastructural project owners always use BIM consultants.

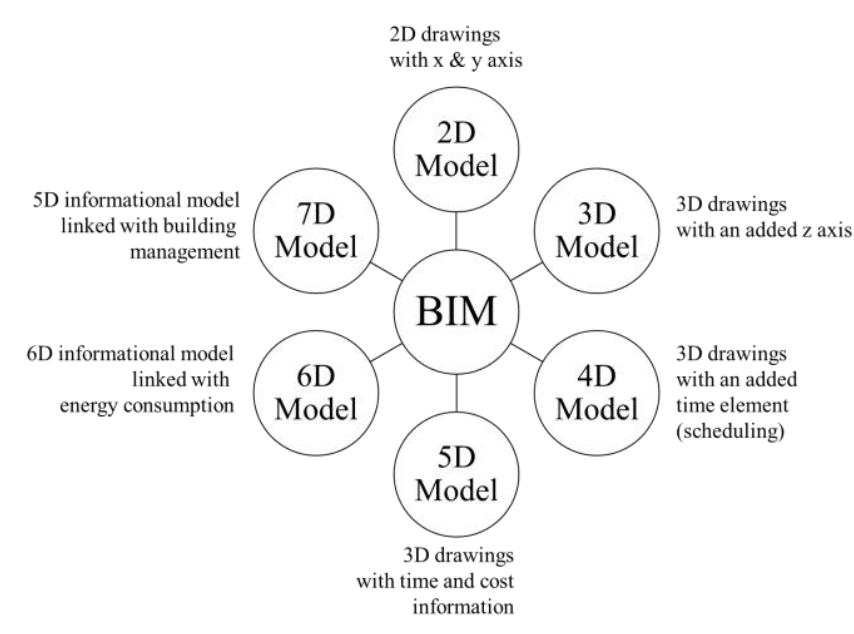

Figure 2. The dimension of BIM and AEC Capability (Azhar, 2011)

\subsection{The Benefits and Constraints of Using BIM}

The infrastructure life-cycle is mainly divided into 3 phases and these include Design (D), Construction $(\mathrm{C})$, and Operations (O) (Succar, 2009). In Indonesia, the project delivery method, especially for each life cycle of government projects, is generally referred to as Design - Bid Build. Moreover, each phase of infrastructure life cycle 4.0 is faced with challenges such as synergy, integration, transparency, accountability, effectiveness, and efficiency. 
However, these challenges can be addressed through the use of BIM for information management (Xu, et al. 2014). According to Succar (2009), the implementation of this technological innovation has the ability to change the relationships, activities, and tasks of life-cycle management. It is also considered as an ideal digital tool to store and manage all data related to the life-cycle of a building (BecerikGerber et.al., 2012) for future utilization (Xu et al., 2014). It also ensures the information from each party starting from the design to the operation and maintenance stage is continuously circulated and updated. It is, therefore, necessary to understand the working process of BIM concerning the flow and exchange of information (Xu et al., 2014).

Another problem observed in the infrastructure life-cycle is the inapplicability of information from one phase in others, for example, inability to use the information provided in the design during construction and, consequently, in the operation phase (Jiao, et al. 2013). BIM is an effective tool to integrate information from several different stages to ensure smooth communication and effective information usage which is the most important element of life-cycle management $(\mathrm{Xu}$, et al. 2014). The technological innovation performs three forms of management and these include collaborative by negotiating different parties with varying software, risk management by reducing the probability and impact of adverse events on the project, and sustainability analysis of complex buildings performance to ensure optimal and sustainable design (Xu et al., 2014).

Each phase of the infrastructure life-cycle involves the activities of several stakeholders including owners, designers, contractors, and facility managers. According to Azhar, et al. (2012), the benefits of BIM for each of them are shown in Table 1.

Several project management sources recognized the advantages of BIM, for example, it was found to have the ability to ensure better project performance and quality, increasing productivity, reducing waste, faster delivery, new opportunities for revenue and business, and low construction costs (Diaz, 2016). According to Bryde et al. (2014), several successful reasons to use BIM include cost reduction followed by time reduction, communication enhancement, coordination, quality improvement, negative risk reduction, and organizational improvement based on the research conducted on 35 projects. Moreover, another study by Fanning et al. (2014) showed the application was able to save costs by $5-9 \%$ during construction.

Table 1 BIM Application for Project Stakeholders

\begin{tabular}{lcccc}
\hline BIM Application & Owners & Designers & Contractors & Facility Managers \\
\hline Visualization & $\sqrt{ }$ & $\sqrt{ }$ & $\sqrt{ }$ & $\sqrt{ }$ \\
Options Analysis & $\sqrt{ }$ & $\sqrt{ }$ & $\sqrt{ }$ \\
Sustainability analysis & $\sqrt{ }$ & $\sqrt{ }$ & $\sqrt{ }$ \\
Quantity survey & & $\sqrt{ }$ & $\sqrt{ }$ \\
Cost estimation & $\sqrt{ }$ & & $\sqrt{ }$ \\
Site logistics & $\sqrt{ }$ & $\sqrt{ }$ & $\sqrt{ }$ \\
Phasing and 4D scheduling & & $\sqrt{ }$ & $\sqrt{ }$ \\
Constructability analysis & & $\sqrt{ }$ & $\sqrt{ }$ \\
Building performance analysis & $\sqrt{ }$ & & \\
Building management & $\sqrt{ }$ & & \\
\hline
\end{tabular}


The advantages of BIM were also summarized in CRC Construction Innovation (2007) to include :

1) Faster and more effective processes: Information is easily shared, adds value and is reused.

2) Better design: Building proposals are rigorously analyzed, simulations performed quickly, and performance benchmarked to enable improved and innovative solutions.

3) Controlled whole-life costs and environmental data: Environmental performance is more predictable, and lifecycle costs are better understood.

4) Better production quality: Documentation output is flexible through the use of automation.

5) Automated assembly: It is possible to use digital product data in downstream processes as well as manufacturing and assembly of structural systems.

6) Better customer service: Proposals are better understood through accurate visualization.

7) Lifecycle data: Requirements, design, construction, and operational information can be used in facilities management.

However, despite these advantages, there are several obstacles to the application of BIM in different countries. According to McGraw Hill Construction data (2014), these constraints include (1) cost/funding/initial investment, (2) training investment/lack of skilled users, (3) adoption on a broad scale and (4) lack of BIM standards throughout the industry. This was also supported by Eadie, et al. (2013) that the software is mostly not used in construction projects due to the lack of expertise among the project team members and several organizations, lack of demand for the use of BIM, investment costs, and the lack of additional project costs to support its application.

\subsection{Future Utilization of BIM in Dam Construction}

Dam with all its complex and detailed facilities requires a tool to integrate and coordinate each stage of construction as well as all the parties involved. For example, the implementation of earthworks involving cut and fill is very complex due to the high level of uncertainty it contains and this means the complete construction of the dam is not guaranteed without changes or deviations from the plan (Rozy, 2015). Moreover, Hidayah, et al. (2018) explained the Work Breakdown Structure (WBS) for main dam work consists of dewatering, earthworks, support and protection, drilling and grouting, top of the dam, drainage of foot dam, instrumentation, and electrical machinery. All of these works have a huge potential for uncertainty considering the project is highly dependent on topographical and geological conditions of the construction site. According to the World Commission on Dams (WCD) (2001), a dam is a complex building with quite expensive costs and, based on 3 dams studied, it was estimated to require USD 6 billion and this one of the reasons it requires a long time of construction ranging from 4 to 6 years. However, BIM has the ability to integrate every stage of the implementation to overcome these problems by estimating costs and using 3D model visualization to immediately monitor changes or deviations.

In the construction process, BIM is also capable of improving design efficiency and quality, reducing costs and misunderstandings between different parties (Matt, 2013), ensuring effective quarry management (Russell \& Jackson, 2014), as well as in designing and manufacturing of pre-cast concrete reservoirs (Russell \& Jackson, 2014). In addition, it has also been implemented in the monitoring process (Coetzee, 2018). However, BIM has not been widely used in dam projects in Indonesia due to several issues such as (1) the absence of qualified human resources (HR) with the knowledge of the software, especially for planners and government/owner (2) lack of 
government regulations requiring the use of the software in the country's dam construction projects, and (3) high initial investment costs to provide software to integrate 3D design, finance, and schedule.

Therefore, the implementation of BIM for dam projects is expected to start from the government through the preparation of regulations requiring the use of BIM from the planning stage. The results obtained in the form of DED would be used by the owner in the bidding process while the contractor is expected to use the shop drawing which has been equipped with cost estimates and scheduling for the construction. Furthermore, the shop drawings would be arranged as-built drawings in accordance with the conditions of the field and later submitted to the government/owner. Through the assessment of the $4 \mathrm{D}$ through 7D capabilities of BIM, it is possible to determine the schedule and estimate costs for the project.

The application of BIM at the operation and maintenance stage of the dam through the process of asset management is another future challenge. Dam, being a vital asset, needs to be well managed because of its numerous benefits to the general public as well as a possible risk of disasters. However, the cost of maintenance and rehabilitation is usually expensive and increases over time. This means there is a need for adequate, timely and quality processes to reduce the burden of funding for maintenance and reengineering. Therefore, BIM has a new level of technical collaboration process designed to facilitate issues of sustainability and asset management (Kivits \& Furneaux, 2013).

BIM as also been reported to have the ability to help the government/owner in taking inventory of some important data related to the construction and management of dams. These include the location of assets, shop and as-built drawings of assets, asset damage history including the time and cost to repair or maintain components and allocation of costs by the government.

\section{CONCLUSION}

Through the review of several pieces of literature, it is possible to apply BIM in dam projects in Indonesia starting from the planning stage, bidding process, construction phase up to the operations and maintenance activities of the dam. It also has the ability to build good coordination among planners, executors/contractors, and consultants to the government/owner as well as in integrating the fields of Architecture, Structure, and Construction (AEC).

Considering the urgency in the application of BIM in future dam projects, planners, contractors, consultants, and government are expected to prepare by ensuring there is:

1. Regulations on the use of BIM in all dam construction projects starting from the planning to construction stage.

2. Initial investment in providing software to integrate and visualize dam construction projects.

3. Training of human resources to use the technological innovation.

\section{DISCLAIMER}

The authors declare no conflict of interest.

\section{REFERENCES}

Autodesk, 2019. What is BIM? [Online] Available at:

https://www.autodesk.com/solutions/bim

Azhar, S., 2011. Building Information Modeling (BIM): Trends, Benefits, Risks, and Challenges for the AEC Industry. Leadership and Management in Engineering, 11(3), pp. 241-252.

Azhar, S., Khalfan, M., \& Maqsood, T., 2012. Building information modeling (BIM): Now and beyond. Australasian Journal of 
Construction Economics and Building, 12(4),

pp.

$15-28$.

https://doi.org/10.5130/ajceb.v12i4.3032

Becerik-Gerber, B., Jazizadeh, F., Li, N., \& Calis, G.. 2012. Application areas and data requirements for BIM-enabled facilities management. Journal of Construction Engineering and Management, 138(3), pp. 431-442.

BIM Ministry of Public Works and Housing, 2019a. Bina Marga Bersiap BIM Mandatory 2020. [Online] Available at: http://bim.pu.go.id/berita/baca/34/binamarga-bersiap-bim-mandatory-2020.html [Accesed 15 September 2019]

BIM Ministry of Public Works and Housing, 2019b. Implementasi BIM di Indonesia Untuk Proyek Bangunan Gedung. [Online] Available at:

http://bim.pu.go.id/berita/baca/42/impleme ntasi-bim-di-indonesia-untuk-proyekbangunan-gedung.html [Accessed 15 September 2019]

Bryde, D., Broquetas, M., \& Volm, J. M., 2014. The project benefits of Building Information Modelling (BIM). International Journal of Project Management, 31(7), pp. 971-980.

Coetzee, G. L., 2018. Smart Construction Monitoring of Dams with UAVS - Neckartal dam Water Project Phase 1. Swansea, Smart Dams and Reservoirs - Proceedings of the 20th Biennial Conference of the British Dam Society.

CRC Construction Innovation, 2007. Adopting BIM for facilities management: Solutions for managing the Sydney Opera House. CRC for construction Innovation participants. Brisbane, Australia: Cooperative Research Center for Construction Innovation.

Diaz, P., 2016. Analysis of Benefits, Advantages and Challenges of Building Information Modelling in Construction Industry. Journal of Advances in Civil Engineering, 2(2), pp. 111.

Directorate General of Human Settlements, 2018.
Kebijakan dan Roadmap Penerapan Building Information Modeling (BIM) Mendukung Konstruksi Digital Indonesia, Semarang.

Eadie, R., Browne, M., Odeyinka, H., McKeown, C., \& McNiff, S., 2013. BIM implementation throughout the UK construction project lifecycle: An analysis. Automation in Construction, 36, pp. 145-151.

Fanning, B., Clevenger, C., Ozbek, M., \& Mahmoud, H., 2014. Implementing BIM on Infrastructure: Comparison of Two Bridge Construction Projects. Practice Periodical on Structural Design and Construction, 20, pp. 4014044.

Hidayah, D. N., Latief, Y., \& Riantini, L. S., 2018. Development of work breakdown structure standard based on risk for safety planning on dam construction work. IOP Conference Series: Materials Science and Engineering, 420(1).

Jiao, Y., Zhang, S., Li, Y., Wang, Y., \& Yang, B., 2013. Towards cloud Augmented Reality for construction application by BIM and SNS integration. Automation in Construction, 33, pp. 37-47.

Ju, K. B., \& Seo, M. B., 2012. A Study on the Issue Analysis for the Application of BIM Technology to Civil Engineering in Korea. Creative Education, 3(7), pp. 21-24.

Kacprzyk, Z., \& Kępa, T., 2014. Building information modelling-4D Modelling technology on the example of the reconstruction stairwell. Procedia Engineering, 91(TFoCE), pp. 226-231.

Kivits, R. A., \& Furneaux, C., 2013. BIM: Enabling sustainability and asset management through knowledge management. The Scientific World Journal, 2013(5).

Matt, B, 2013. Model-based Design Powers China Dam Construction, West Allis : Informed Infrastructure.

McArthur, J. J., 2015) A Building Information Management (BIM) Framework and Supporting Case Study for Existing Building Operations, Maintenance and Sustainability. 
Procedia Engineering, 118, pp. 1104-1111.

McGraw Hill Construction, 2014. The Business Value of BIM for Owners. SmartMarket Report. (Harvey M. Bernstein, Ed.), Bedford.

Ministry of Public Works and Housing, 2017. BIM Roadmap Indonesia. [Online] Available at: http://bim.pu.go.id/assets/files/ROADMAP_ KONSTRUKSI_DIGITAL_INDONESIA_14091 7.pdf

Mulyono, J., 2017. Konsepsi Keamanan Bendungan dalam Pembangunan dan Pengelolaan Bendungan. Jurnal Infrastruktur, 3(01), pp. 62-69.

Paul, S, 2018. BIM adoption around the world: how good are we? [Online] Available at: https://www.geospatialworld.net/article/bi m-adoption-around-the-world-how-goodare-we/

Ratajczak, J., Marcher, C., Schimanski, C. P., Schweikopfler, A., Riedl, M., \& Matt, D. T., 2019. BIM-based augmented reality tool for the monitoring of construction performance and progress. Chania, Proceedings of the 2019 European Conference for Computing in Construction.

Rozy, N., 2015. Pengaruh Jenis dan Susunan Armada Alat Berat Pekerjaan Tanah Terhadap Optimasi Biaya dan Waktu. Jurnal Logika, XIII(1), pp. 96-206.

Russell, S., \& Jackson, T., 2014. Construction of a pre-cast concrete service reservoir using BIM. Belfast, Maintaining the Safety of Our Dams and Reservoirs - Proceedings of the 18th
Biennial Conference of the British Dam Society.

Schurer, J., Wilkinson, E., Norfleet, J., Sciver, J. Van, Huntington, C., Lee, C., \& Rogers, A., 2002. Dam Safety Manual (3th ed.). Colorado: Members of the Colorado Division of Water Resources.

Succar, B., 2009. Building information modelling framework: A research and delivery foundation for industry stakeholders. Automation in Construction, 18(3), pp. 357375.

U.S. Department of Homeland Security., 2007. Dams Sector Security Awareness Handbook.

Wang, K. C., Wang, S. H., Kung, C. J., Weng, S. W., \& Wang, W. C., 2018. Applying BIM and visualization techniques to support construction quality management for soil and water conservation construction projects. Berlin, ISARC 2018 - 35th International Symposium on Automation and Robotics in Construction and International AEC/FM Hackathon: The Future of Building Things, (Isarc).

World Commission on Dams (WCD)., 2001. Dambuilding decisions. Environmental Health Perspective, 109(2), pp. 81-83.

Xu, X., Ma, L., \& Ding, L., 2014. A framework for BIM-enabled life-cycle information management of construction project. International Journal of Advanced Robotic Systems, 11(1), pp. 1-13. 